\title{
THE IMPORTANCE OF EARLY DETECTION OF NEUROPHIBROMATOSIS
}

Zoranka Vlatković, Vinka Repac, Marija Repac

\section{Сажнетак}

Von Recklinghausen-ова болест спада y факоматозе. То је наследно обољење са многобројним туморима по телу и пигментацијом коже. Наслеђује се аутозомно доминантно. Уколико један родитељь има неурофиброматозу, шанса да је дете наследи је 50\%. Најчешћи неуролошки поремећаји y детиюству су когнитивни поремећаји и проблем у учењу (80\%). У овом раду приказујемо значај раног откривања ове болести код деце са породичном предиспозијијом као и сам даљи ток праћења оболелог.

Кључни речи: генетика, дете, превенџија, неурофиброматоза.

\begin{abstract}
Summary
Von Recklinghausens disease belongs to phacomatosis. It is a hereditary disease with numerous tumors on the body and with pigmentation of the skin. It is inherited autosomely dominantly. If one parent has neurofibromatosis, the chance that the child inherites it is 50\%. The most common neurological disorders in childhood are congenital disorders and learning problems (80\%). In this paper we will show the importance of early detection of this disease in children with a family predisposition, as well as the further course of follow-up of the diseased patient.
\end{abstract}

Key Words: genetics, a child, prevention, neurofibromatosis.

\footnotetext{
${ }^{1}$ Др мед. Зоранка Влатковић, специјалиста педијатрије, Дом здравља Житиште (Community Health Centre), Житиште, Србија.

${ }^{2}$ Прим. др мед. Винка Репац, специјалиста офталмологије, Дом здравља Житиште (Community Health Centre), Житиште, Србија.

${ }^{3}$ Марија Репац, студент, Природно математички факултет, Нови Сад (Faculty of Sciences, Novi Sad), Србија.
} 
Увод

$\mathrm{V}$

on Recklinghausen-ова болест спада у факоматозе.То је наследно обољење са многобројним туморима по телу и пигментацијом коже. Узрок је мутација НФ-1 гена на хромозому 17. Овај ген је један од највећих гена људског генома (око 100.000 базних парова), тако да је вероватноћа појаве мутације прилично велика у односу на друге гене. Овај ген регулише ћелијску деобу - митозу, па се његовом мутацијом ћелије убрзано размножавају, тј. настаје тумор. Овај ген припада такозваним протоонкогенима. Њиховом мутацијом настају онкогени који узрокују настанак тумора. Наслеђује се аутозомно доминантно. Уколико један родитељ има неурофиброматозу, шанса да је дете наследи је 50\%. Најчешћи неуролошки поремећаји у детињству су когнитивни поремећаји и проблем у учењу $(80 \%)$. Периферни кутани и субкутани неурофиброми се обично јављају у пубертету. Учесталост малигних тумора овојница периферног нервног система, неурофибросаркома, већа је него у општој популацији и процењује се на 2-5\%. Оптички глиоми (астроцитоми) су најчешћи тумори мозга код деце са НФ-1 (20\%). Други по учесталости су тумори можданог стабла. Промене у виду флека „беле кафе“ у пазушној и ингвиналној регији. Најчешћи офталмолошки налаз је појава Lischov-их нодуса на ирису. Често се као удружени налаз описује појава неурофиброматозе горњег капка, глиом видног живца, хориоидални хамартроми и конгенитални глауком. ${ }^{(1,2,3)}$

\section{ЦИЉ РАДА}

Циљ рада је указивање на значај правовремене дијагностике и превенције компликација код неурофиброматозе тип 1, изношењем приказа случаја оболелог детета.

\section{МАТЕРИЈАЛ И МЕТОД РАДА}

Пацијент - дете женског пола у пракси примарне здравствене заштите са неурофиброматозом тип 1 описано уз коришћење података из лекарских извештаја и отпусне листе, и одговарајућа литература основа су за анализу случаја из праксе у погледу утврђивања значаја правовремене дијагнозе и превеције компликација код неурофиброматозе тип 1.

\section{ОПИС ПАЦИЈЕНТА ИЗ ПРАКСЕ}

У оквиру припреме пацијента за тонзилектомију прегледано је женско дете старо девет година од стране оториноларинголога, где је постављена радна дијагноза неурофиброматоза. У анамнези је утврђено да дете живи са бабом која има специфичне кутане промене, а баба даје и податак да унука „теже памти“, и да њена ћерка, мајка детета, има идентичне промене на кожи као и она. Прегледом је уочено да су многобројни мултипли фиброми прекривали леђа и абдомен бабе. Код детета су запажене промене на лицу које су биле у виду „флека од беле кафе“, као и у пределу абдомена, а по две веће од $5 \mathrm{~mm}-15 \mathrm{~mm}$ биле су у пазушној јами и у пределу препона (укупно више од 6). Видна оштрина са корекцијом оба ока је била 0,7 (ВОД: са ц/ц=0,7; ТОД: $14 \mathrm{mmHg}$; BOC: са ц/ц=0,7; TOC: $13 \mathrm{mmHg}$.

Узимајући у обзир узраст детета, измерен је интраокуларни притисак, апланационим тонометром по Голдманну у капљичној локалној анестезији (Gutt. Tetracain 0,5\%). Прегледом предњег сегмента ока бинокуларним микроскопом, најизраженије промене су биле на дужици у виду Lischovих чворића, у доњој половини. Прегледом очног дна индиректном офталмоскопијом, папила је била јасних граница, нешто блеђа горе и темпорално. Консултован је неуролог, урађена НМР којом је утврђена лака редукција кортекса. Радиолози су описали коштане лезије на дугим костима. Није 
било проширења оптичких канала и путева посматраних на РТГ снимку.

Слика 1. Промене на кожи детета.

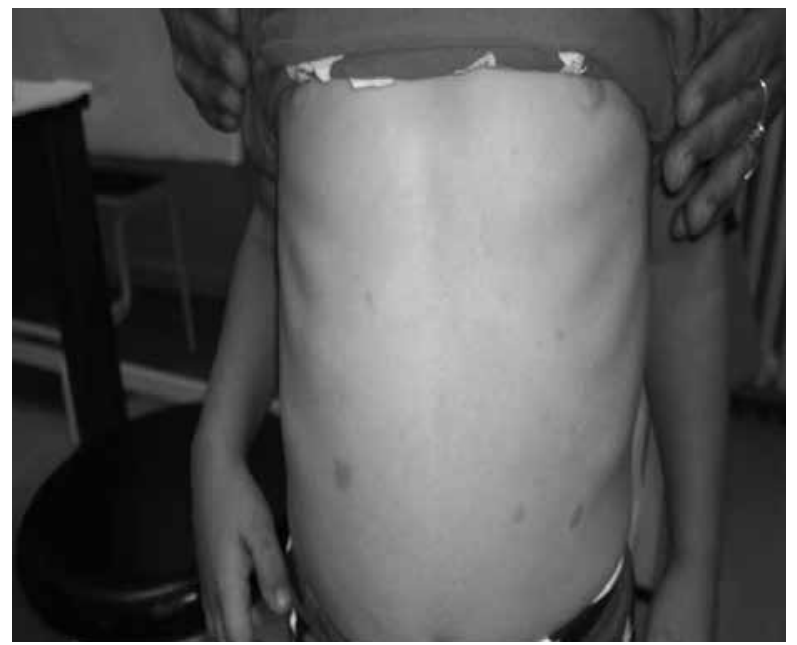

Слика 2. Промене на кожи бабе детета.

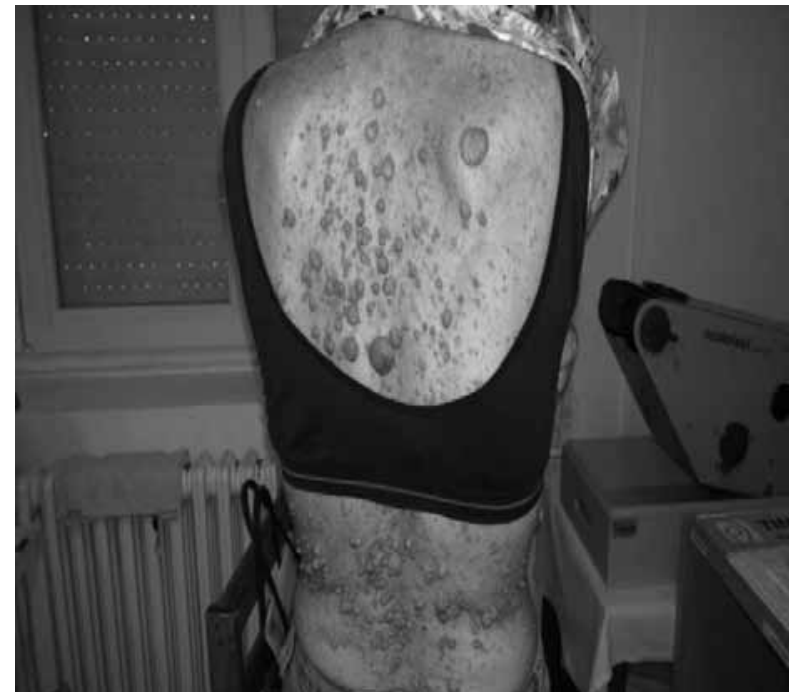

Слика 3. Lichov-и чворићи на ирису детета.

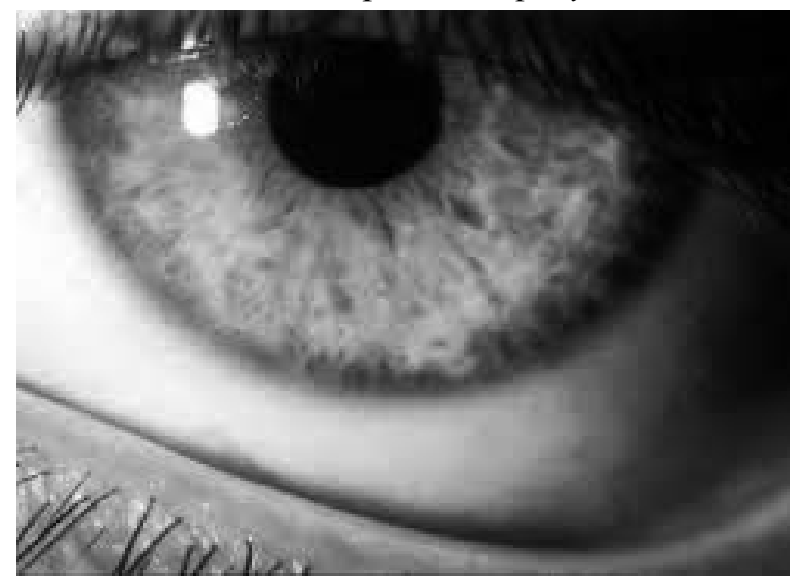

Слика 4. Очно дно детета.

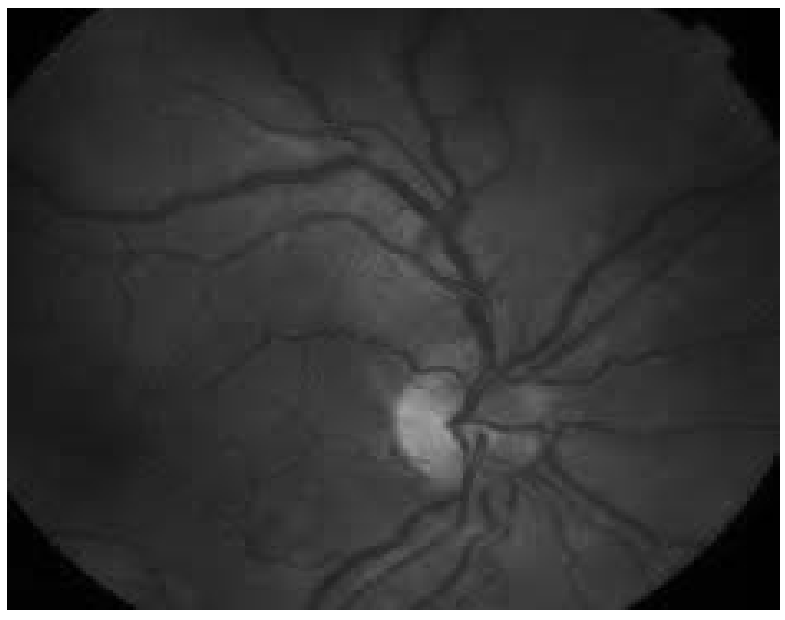

\section{ДИСКУСИЈА}

Неурофиброматоза тип 1, неурофиброматоза тип 2 и шваноматоза имају различиту клиничку слику, различите гене на различитим хромозомима. Могу бити наслеђене од родитеља који имају НФ или су први случај у породици као резултат нове или спонтане промене гена настале у полним ћелијама (сперматозоид, јајна ћелија). У току ембрионалног развоја кожа и мозак се развијају из исте основе - неуралног гребена, због тога се ове болести сврставају у групу неурокутаних болести или факоматоза. Основни критеријуми за постављање дијагнозе су:

- $\geq 6$ мрља боје беле кафе која су на најширем месту пречника $>5 \mathrm{~mm}$, након пубертета $>15 \mathrm{~mm}$;

- $\geq 2$ неурофиброма било ког типа или 1 плексиформни неурофибром;

- стварање мрља у пазуху или препонама;

- оптички глиом;

- $\geq 2$ Lischov-a чворића (хамартоми дужице);

- јасна промена на костима / сфеноидна дисплазија - недостатак великог крила сфеноидне кости који чини задњи зид орбите има за последицу пулсирајући егзофталмус; 
- родитељ, брат или сестра са дијагностикованом неурофиброматозом тип 1.

У оквиру неурофиброматозе тип 1 могу се јавити и неки малигни тумори као што су ретинобластома, феохромоцитом, малигни глиом оптичког нерва, као и коштани деформитети. ${ }^{(4,5,6)}$ Многобројне офталмолошке манифестације могу бити удружене са овом релативно честом болешћу. Присуство глиома видног живца, глијалног хемартома ретине и оптичког диска, сектораста пигментација ретине и хемартоми хориоидее, нису регистровани код детета, али се јављаjу у $2-3 \%$ код болесника са фиброматозом тип 1. У литератури се описује и појава конгениталног глаукома услед присуства меланоцитних нодуса у трабекуларном систему. $(7,8,9)$ Вредности интраокуларног притиска ове девојчице су у физиолошким границама. Неурофиброматоза тип 1 је најчешће заступљена у групи факоматоза. ${ }^{(10,11)}$ У презентованом случају пад видне оштрине и промене на очном дну су највероватније последица промена на кортексу, јер нема глиома оптикуса. У литератури су описани случајеви праћени епилептичним нападима, али га ово дете није имало. Кожне промене су упечатљиве и препознатљиве, али се морају адеквантно евидентирати. Наш пример показује колико је значајна инспекција, као и добра анамнеза на нивоу примарне здрав- ствене заштите. Неурофиброматоза тип 1 се јавља на сваких 4.500 новорођенчади. Статистички подаци показују да су припадници свих етничких група и раса подједнако погођени са једнаком заступљеношћу међу половима. Ови пацијенти имају повећан ризик од развоја малигних тумора, леукемије, повишеног крвног притиска ортопедских проблема. Неурофиброматоза се не може излечити, али је неопходно стално праћење стања оболелог и ублажавати симптоме, покушавајући да се спрече.

\section{ЗАКЈУЧАК}

Приликом in vitro оплодње могу се начинити генетска тестирања, а веома је битно и адекватно генетско саветовалиште. Такође, узорковање хорионских чупица и крви из пупчаника могу помоћи да се направи генетски скрининг. Генетско саветовање је део здравственог система. Ако се ради о аутозомно-доминантној болести, деца оболелих имају ризик од $50 \%$ за наслеђивање гена родитеља. Неопходно је урадити детаљну анализу родословног стабла, као и преглед родитеља (ако нису старији од 60 година). Поред детаљног дерматолошког и офталмолошког прегледа неопходно је урадити и слушне евоциране потенцијале као и МРИ ендокранијума како би се искључила и НФ-2.

\section{ЛИТЕРАТУРА}

1. Станојевић-Паовић А, Миленковић $\mathrm{C}$, Златановић Г. Системске болести и око. Медицински факултет, Београд, 1993; 171-2.

2. Сабол 3, Гјергија 3. и сар. Неуролошке промене и компликације у деце с неурофиброматозом тип 1. Pediatria croat, 2008; 52(3): 141-149.

3. Pollack F, Shultz B, Mulvihill J. The managment of brainsterm gliomas in patients with neurofibromatosis 1 . Neurology 1996; 46: 1652-60.

4. Listernick R, Ferner R, Piersall L, Sharif S, Gutmann D, Charrow J. Late-oset optic pathway in children with neurofibromatosis 1. Neurology 2004; 63: 1944-6.

5. Lammert M, Kappler M, Mautner V, Lamment K, Storkel S, Friedman J, Atkins D. Decreased bone mineraly density in patients with neurofibromatosis 1 . Osteoporosis Int 2005; 16: 1161-6.

6. Crawlett A, Bagamery N. Osseous manifestations of neurofibromatosis in chilhood. J pediatr Orthop 1986; 6: 72-88. 
7. Dimitrova V, Yordanova I, Pavlova V, Valchev, Gospodinov D, Parashkevova B, Balabanov C. A case of neurofibromatosis type 1. Journal of IMAB 2008; 1, 63-7.

8. Balsalobre A, Gonzales C, Verdu M. Optic nerve glioma in a cases of neurofibromatozis-1 in a child. Arch soc esp ophthalmol 2006; 81: 33-6.

9. Сабол 3, Кипке-Сабол Љ, Микић П. и сар. Неурофиброматоза тип 2 (Централна неурофиброматоза или билатерални акустички неуроми, вестибуларни (ваноми): од фенотипа до гена. Лијеч. Вјесн 2006; 128: 309-316.

10. Leverkus M, Kluwe L, Roll EM. i sur. Multiple unilateral schwannomas: segmental neurofibromatosis type 2 or schwannomatosis. Br J Dermatol 2003; 148: 804-9.

11. Васић Б, Јеленковић Б, Јовановић Љ, Влајић Е. Неурокутани синдроми у десетогодишњем периоду у Зајечару. Зборник сажетака, XXXIV Тимочки медицински дани, 2015; 40: 58.

Контакт: Др мед. Зоранка Влатковић, Дом здравља Житиште, И. Л. Рибара 16, 23210

Житиште, Србија, тел. 02382101, моб. 0642242573, e-mail: zoranka.vlatkovic@gmail.com 